\title{
HUBUNGAN PARITAS DAN RIWAYAT PREEKSLAMSI PADA PERSALINAN YANG LALU DENGAN KEJADIAN PREEKLAMSI PADA IBU BERSALIN DI RSU SUNDARI MEDAN
}

\author{
Dodoh Khodijah \\ Poltekkes Kemenkes Medan Jurusan Kebidanan
}

\begin{abstract}
Abstrak
Latar Belakang: Salah satu penyebab kematian ibu di Sumatera Utara sebanyak $10 \%$ disebabkan oleh preeklamsi/eklamsi. Faktor yang mempengaruhi kejadian preeklamsi diantaranya paritas, dan riwayat reeklampsi pada persalinan yang lalu. Tujuan: untuk mengetahui variabel paritas dan riwayat persalinan yang lalu dengan terjadinya preeklamsi pada ibu bersalin di RSU Sundari Medan Tahun 2014. Metode : Penelitian ini bersifat analitik dengan pendekatan cross sectional dan menggunakan data sekunder yang diperoleh dari rekam medik dengan populasi seluruh ibu bersalin di RSU Sundari Medan, Sampel dalam penelitian ini adalah ibu yang mengalami preeklamsi di ruang bersalin RSU Sundari Medan yang berjumlah 52 orang. Analisa data dilakukan dengan uji Chi Square dengan $p \leq 0,05$. Hasil : Variabel paritas tidak mempunyai hubungan dengan kejadian preeklamsi dengan nilai $P: 0,65$ dan dan variabel riwayat preeklamsi pada persalinan yang lalu terhadap terjadinya preeklamsi tidak mempunyai hubungan yang bermakna. Kesimpulan dan saran: Melakukan pemeriksaan kehamilan minimal 4 x selama kehamilan dapat mendeteksi adanya penyulit pada kehamilan khususnya mendeteksi preekslampsi.
\end{abstract}

Kata Kunci : paritas, riwayat preeklamsi sebelumnya dan preeklamsi

\section{Latar Belakang}

Kehamilan dan persalinan merupakan proses alamiah, tetapi bukannya tanpa risiko dan merupakan beban tersendiri bagi seorang wanita. Sebagian ibu hamil akan menghadapi kegawatan dengan derajat ringan sampai berat yang dapat memberikan bahaya terjadinya ketidaknyamanan, ketidakpuasan, kesakitan, kecacatan bahkan kematian bagi ibu dan bayinya (Nursalam 2006).

Menurut Abdullah (2007) komplikasi kehamilan, persalinan dan nifas merupakan masalah kesehatan yang penting, bila tidak ditanggulangi akan menyebabkan angka kematian ibu (AKI) yang tinggi. Kematian seorang ibu dalam proses reproduksi merupakan tragedi yang mencemaskan. Keberadaan seorang ibu merupakan tonggak untuk tercapainya keluarga yang sejahtera dan kematian seorang ibu merupakan suatu bencana bagi keluarganya. Dampak sosial dan ekonomi kejadian ini dapat dipastikan sangat besar, baik bagi keluarga, masyarakat maupun angkatan kerja.

Angka Kematian Ibu di Sub-sahara Afrika 270/100.000 kelahiran hidup, di Asia Selatan 188/100.000 kelahiran hidup, di Asia Tenggara 35/100.000, AKI di Singapura 14/100.000 kelahiran hidup, di Malaysia 62/100.000 kelahiran hidup, di Thailand 110/100.000 kelahiran hidup, di Vietnam 150/100.000 kelahiran hidup, di Filipina 230/100.000 kelahiran hidup dan di Myanmar 380/100.000 kelahiran hidup (WHO. 2010). AKI di Indonesia pada tahun 2007 dan 2008 berturut turut sebesar 228/100.000 kelahiran hidup dan 226/100.000 kelahiran hidup (Satyoputro, 2012).

Menurut Nila (2012) yang dimuat dalam Tempo.Co tahun 2012 AKI di Indonesia mencapai 162/100.000 kelahiran hidup artinya, dalam $100.000 \mathrm{ibu}$ terdapat 162 ibu yang meninggal dunia karena melahirkan padahal target Millenium Development Goals (MDGs) tahun 2015 adalah 102/100.000.

Menurut Endang (2012) yang dimuat dalam Harian Analisa (2012) bidan memiliki peran yang penting dalam membantu pemerintah untuk mencapai (MDGs) 2015 khususnya dalam menekan Angka Kematian Bayi (AKB) dan AKI. Bidan sebagai ujung tombak dalam menekan AKI dan AKB, sehingga para calon-calon bidan harus sadar dan paham akan keprofesionalitasannya dalam bertugas, tidak hanya itu, hal tersebut menjadikan bidan juga memiliki posisi yang strategis dalam penyuksesan MDGs 2015 yang dicanangkan pemerintah. Program MDGs 2015 Pemerintah Indonesia yang salah satu pointnya adalah menekan AKI dan AKB masih sangat jauh dari harapan. Setiap tahun dari data yang dihimpun kematian bayi mencapai 20 bayi per jam dan dan hampir 50 persen meninggal di bulan pertama, sedangkan angka kematian ibu dari data tahun 2007 menunjukkan setiap tiga jam sedikitnya ada satu ibu meninggal atau ada 10.260 kematian ibu setiap tahunnya.

Menurut Yeni (2011) yang dimuat dalam Starberita (2011) AKI di Sumatera Utara secara nasional mencapai 228/100.000 jumlah kelahiran hidup. Pada 2007 AKI mencapai 231/100.000 kelahiran hidup, pada 2008, 
AKI ini meningkat menjadi 258/100.000 kelahiran hidup, pada tahun 2009 AKI menjadi 260/100.000 kelahiran hidup, dan pada tahun 2010 mencapai 249/100.000 kelahiran hidup.

Menurut Dinkes Provinsi Sumatera Utara penyebab utama AKI di Sumatera Utara belum ada survey khusus, tetapi secara nasional oleh karena komplikasi persalinan $(45 \%)$, retensio plasenta $(20 \%)$, robekan jalan lahir (19\%), partus lama (11\%), perdarahan dan eklamsi masing - masing (10\%), komplikasi selama nifas (5\%) dan demam nifas (4\%) (Dinkes Provsu, 2008). Angka kejadian preeklamsi berkisar antara 5-15\% dari seluruh kehamilan di seluruh dunia. Di United Kingdom (UK), preeklamsi/eklampsia terhitung sebanyak 10-15\% dari kematian obstetrik langsung (Duley, 2003).

Menurut Rossa (2009) yang dikutip oleh Addy (2009) di Sumatera Utara dilaporkan bahwa kasus preeklamsi di RSUP. H. Adam Malik Medan pada tahun 2005-2006 terdapat 30 kasus dan di Rumah Sakit Umum Daerah (RSUD) Dr. Pirngadi Medan tahun 2009 terdapat 33 ibu yang mengalami preeklamsi

Berdasarkan survei awal di Rumah Sakit Umum Sundari Medan, dari catatan rekam medik Tahun 2014 terdapat $2138 \mathrm{ibu}$ bersalin dan $52(2,43 \%)$ ibu yang mengalami preeklamsi.

Berdasarkan latar belakang di atas, maka penulis tertarik untuk melakukan penelitian yang berjudul “ hubungan paritas dan riwayat preeklamsi sebelumnya dengan kejadian Preeklamsi Pada Ibu Bersalin di RSU Sundari Medan".

\section{Perumusan Masalah}

Bagaimana hubungan paritas dan riwayat preeklamsi sebelumnya dengan kejadian Preeklamsi Pada Ibu Bersalin di RSU Sundari Medan?

\section{Tujuan Penelitian}

Untuk mengetahui hubungan paritas dan riwayat preeklamsi sebelumnya dengan kejadian Preeklamsi Pada Ibu Bersalin di RSU Sundari Medan.

\section{Manfaat Penelitian}

Secara Teoritis : untuk menambah wawasan, pengetahuan, dan pengalaman penulis dalam melakukan penelitian khususnya tentang preeklamsi yang berkaitan dengan paritas dan riwayat preeklamsi pada persalinan yang lalu.

\section{Secara Praktis :}

Sebagai bahan informasi bagi tenaga kesehatan untuk dapat mendeteksi dini dan melakukan penanganan segera pada preeklamsi.

\section{Metode Penelitian:}

Jenis penelitian ini bersifat analitik observasional dengan pendekatan crossectional untuk melihat hubungan paritas dan riwayat persalinan yang lalu dengan kejadian preeklamsi pada ibu bersalin di RSU Sundari Medan Tahun 2014. Data diperoleh dari catatan medik pasien, dengan populasi seluruh ibu bersalin di RSU Sundari
Medan, Sampel dalam penelitian ini adalah ibu yang mengalami preeklamsi di ruang bersalin RSU Sundari Medan yang berjumlah 52 orang. Analisa data dilakukan dengan uji Chi Square dengan $p \leq 0,05$.

\section{Hasil Penelitian}

Dari 56 sampel yang ada di RSU Sundari pada tahun 2014 diperoleh hasil sebagai berikut:

Tabel 1. Distribusi Frekwensi Preeklamsi berdasarkan Umur di RSU Sundari Medan Tahun 2014

\begin{tabular}{|l|c|c|}
\hline \multicolumn{1}{|c|}{ Umur } & $\begin{array}{c}\text { Frekuensi } \\
(\mathbf{F})\end{array}$ & $\begin{array}{c}\text { Persentase } \\
(\mathbf{\%})\end{array}$ \\
\hline$<20 />35$ tahun & 13 & 25 \\
\hline $20-35$ tahun & 39 & 75 \\
\hline Total & 52 & 100 \\
\hline
\end{tabular}

Pada tabel 1 diperoleh ibu bersalin yang mengalami preeklamsi kelompok umur resiko rendah (20-35 tahun) sebanyak 39 orang $(75 \%)$, dan kelompok umur resiko tinggi <20/> 35 tahun sebanyak 13 orang $(25 \%)$.

Tabel 2 Distribusi Frekuensi Preeklamsi Berdasarkan Paritas Di RSU Sundari Medan Tahun 2014

\begin{tabular}{|c|c|c|}
\hline Paritas & $\begin{array}{c}\text { Frekuansi } \\
(\mathbf{F})\end{array}$ & $\begin{array}{c}\text { Persentase } \\
(\mathbf{\%})\end{array}$ \\
\hline $\begin{array}{c}\text { Primipara/ } \\
\text { Grande multipara }\end{array}$ & 34 & 65,34 \\
\hline Multipara & 18 & 34,61 \\
\hline Total & 52 & $100 \%$ \\
\hline
\end{tabular}

Berdasarkan tabel 2 dapat dilihat ibu bersalin yang mengalami preeklamsi adalah kelompok resiko tinggi (primipara/grandemultipara) sebanyak 34 orang $(65,34 \%)$, dan kelompok resiko rendah (multipara) sebanyak 18 orang $(34,61 \%)$.

\section{Distribusi Riwayat Persalinan Yang Lalu}

Melalui catatan rekam medik ibu bersalin dengan preeklamsi di RSU Sundari Medan Tahun 2014, diperoleh data riwayat persalinan yang lalu kemudian data dianalisis dan disajikan dalam bentuk tabel distribusi frekuensi seperti dibawah ini :

Tabel 3 Distribusi Frekuensi Preeklamsi Berdasarkan Riwayat Preeklamsi pada Persalinan Sebelumnya di RSU Sundari Medan Tahun 2014

\begin{tabular}{|c|c|c|}
\hline $\begin{array}{c}\text { Riwayat } \\
\text { Preeklamsi } \\
\text { Sebelumnya }\end{array}$ & $\begin{array}{c}\text { Frekuansi } \\
(\mathbf{F})\end{array}$ & $\begin{array}{c}\text { Persentase } \\
(\boldsymbol{\%})\end{array}$ \\
\hline Ya & 0 & 0 \\
\hline Tidak & 52 & 100 \\
\hline Total & 52 & 100 \\
\hline
\end{tabular}

Berdasarkan tabel 3 dapat diketahui seluruh ibu bersalin yang mengalami preeklamsi tidak pernah mengalami riwayat preeklamsi sebelumnya. 


\section{Hubungan Paritas Dengan Preeklamsi Pada Ibu Bersalin Di RSU Sundari Medan Tahun 2014}

Faktor-faktor yang berhubungan dengan terjadinya preeklamsi pada ibu bersalin di RSU Sundari Medan Tahun 2014 berdasarkan paritas dapat dilihat pada tabel berikut :

Tabel 4 Distribusi Preeklamsi Berdasarkan Paritas Di RSU Sundari Medan Tahun 2014

\begin{tabular}{|c|c|c|c|c|c|c|}
\hline \multirow{2}{*}{ Paritas } & \multicolumn{4}{|c|}{ Preeklamsi } & \multicolumn{2}{c|}{ Total } \\
\cline { 2 - 6 } & \multicolumn{2}{|c|}{ Ya } & \multicolumn{2}{c|}{ Tidak } & \multicolumn{2}{c|}{} \\
\cline { 2 - 6 } & F & \% & F & \% & F & \% \\
\hline $\begin{array}{c}\text { Primipara/ } \\
\text { Grandemultipara }\end{array}$ & 34 & 32,7 & 30 & 28,9 & 64 & 61,6 \\
\hline Multipara & 18 & 17,3 & 22 & 21,1 & 40 & 38,4 \\
\hline Total & 52 & 50 & 52 & 50 & 104 & 100 \\
\hline
\end{tabular}

Setelah dilakukan uji chi-kuadrat untuk mencari hubungan antara paritas dengan terjadinya preeklamsi, diperoleh $\mathrm{x}_{\text {tabel }}^{2}$ sebesar 3,481 dan $\mathrm{x}_{\text {hitung }}^{2}$ sebesar 0,65. Oleh karena $x_{\text {hitung }}^{2}$ lebih kecil dari $x_{\text {tabel }}^{2}(0,65<3,481)$ maka Ho diterima dapat dinyatakan bahwa tidak ada hubungan yang signifikan antara paritas dengan terjadinya preeklamsi pada ibu bersalin

Hubungan Riwayat Persalinan yang Lalu dengan Preeklamsi pada Ibu Bersalin di RSU Sundari Medan Tahun 2014

Faktor-faktor yang berhubungan dengan terjadinya preeklamsi pada ibu bersalin di RSU Sundari Medan Tahun 2012 berdasarkan Riwayat persalinan yang lalu dapat dilihat pada tabel berikut :

Tabel 5 Distribusi Frekuensi Preeklamsi Berdasarkan Riwayat Preeklamsi Sebelumnya Di RSU Sundari Medan Tahun 2014

\begin{tabular}{|c|c|c|c|c|c|c|}
\hline Riwayat & \multicolumn{4}{|c|}{ Preeklamsi } & \multicolumn{2}{c|}{ Total } \\
\cline { 2 - 5 } $\begin{array}{c}\text { Preeklamsi } \\
\text { Sebelumnya }\end{array}$ & \multicolumn{2}{|c|}{ Ya } & \multicolumn{2}{c|}{ Tidak } & \multicolumn{2}{c|}{} \\
\cline { 2 - 7 } & F & $\%$ & F & \% & F & $\%$ \\
\hline Ya & 0 & 0 & 0 & 0 & 0 & 0 \\
\hline Tidak & 52 & $50 \%$ & 52 & $50 \%$ & 104 & $100 \%$ \\
\hline Total & 52 & $50 \%$ & 52 & $50 \%$ & 104 & $100 \%$ \\
\hline
\end{tabular}

Setelah dilakukan uji chi-kuadrat untuk mencari hubungan antara riwayat preeklamsi sebelumnya, hasil analisis diperoleh $\mathrm{x}_{\text {tabel }}^{2}$ sebesar 3,481 dan $x^{2}$ hitung sebesar 0 . Oleh karena $x^{2}{ }_{\text {hitung }}$ lebih kecil dari $\mathrm{x}_{\text {tabel }}^{2}(0<3,481)$ maka Ho diterima dapat dinyatakan bahwa tidak ada hubungan yang signifikan antara riwayat preeklamsi sebelumnya dengan terjadinya preeklamsi pada ibu bersalin.

\section{Pembahasan \\ Paritas}

Paritas adalah jumlah janin Paritas merupakan faktor risiko terjadinya preeklamsi. Menurut Wiknjosastro, H. (2002), frekuensinya lebih tinggi terjadi pada primigravida daripada multigravida. Hasil penelitian yang telah dilakukan oleh peneliti dari 52 orang responden pada ibu bersalin yang menderita preeklamsi dtemukan bahwa preeklamsi terjadi paling banyak terjadi pada kelompok ibu dengan risiko tinggi. Pada tabel 4 menunjukkan pada kelompok primipara/grandemultipara angka kejadian preeklamsi sebanyak 34 orang $(65,34 \%)$. Hal ini sesuai dengan pernyataan Wiknjosastro (2002), frekuensi lebih tinggi terjadi pada primigravida daripada multigravida. Berdasarkan teori immunologik yang disampaikan Sudhaberata (2005) hal ini di karenakan pada kehamilan pertama terjadi pembentukan "blocking antibodies" terhadap antigen yang tidak sempurna. Selain itu menurut Angsar, D (2004), pada kehamilan pertama terjadi pembentukan "Human Leucocyte Antigen Protein G (HLA)" yang berperan penting dalam modulasi respon immune, sehingga ibu menolak hasil konsepsi (plasenta) atau terjadi intoleransi ibu terhadap plasenta sehingga terjadi preeklamsia

Hasil penelitian Ayurai (2007) menyebutkan bahwa kejadian preeklamsi sebagian besar adalah pada kelompok multigravida dan tidak ada hubungan antara paritas dengan kejadian preeklamsi.

Menurut asumsi penulis tidak ada hubungan antara faktor paritas dengan terjadinya preeklamsi, pada data diperoleh bahwa ibu yang mengalami preeklamsi juga terdapat pada paritas resiko rendah (multipara) sebanyak 18 orang $(34,61 \%)$, hasil penelitian ini sejalan dengan penelitian Ayurai (2007). Walaupun penelitian yang dilakukan terhadap preeklamsi sudah maju namun penyebab preeklamsi belum diketahui pasti hanya disasarkan pada teori yang dihubungkan dengan kejadian. Banyak faktor-faktor lain yang berisiko dengan terjadinya preeklamsi seperti obesitas, faktor genetik, faktor suami, riwayat penyakit hipertensi krronik dan penyakit ginjal kronik.

\section{Riwayat Preeklamsi pada persalinan sebelumnya}

Berdasarkan hasil penelitian yang telah dilakukan oleh peneliti dari 52 orang responden yang menjadi objek penelitian, ibu yang pernah mengalami preeklamsi pada persalinan seluruhnya tidak mempunyai riwayat preeklamsi sebelumnya yaitu 52 orang $(100 \%)$.

Menurut Mitayani (2009) dan Norwitz (2010) riwayat preeklamsi pada kehamilan dan persalinan dapat menyebabkan preeklamsi.

Hasil penelitian Agung Supriandono (2007) dan Sulchan Sofoewan yang dikutip oleh Rozikhan (2012) menyebutkan bahwa terdapat $83 \quad(50,9 \%)$ kasus preeklapmsia mempunyai riwayat preeklapmsia, sedangkan pada kelompok kontrol terdapat $12(7,3 \%)$ mempunyia riwayat preeklamsi berat, hasil uji statistik terdapat hubungan antara riwayat preeklamsi sebelumnya dengan kejadian preeklamsi.

Menurut asumsi penulis tidak ada hubungan antara riwayat pre-ekamsia sebelumnya dengan terjadinya preeklamsi, seluruh ibu yang mengalami preeklamsi tidak mempunyai riwayat preeklamsi pada persalinan sebelumnya. Hasil penelitian ini berbeda dengan pendapat Agung Supriandono (2007) dan Sulchan Sofoewan yang dikutip oleh Rozikhan (2012) hal tersebut mungkin karena perbedaan tempat dan waktu penelitian. Walaupun penelitian yang dilakukan terhadap preeklamsi sudah maju namun penyebab preeklamsi belum diketahui pasti hanya disasarkan pada teori yang dihubungkan dengan kejadian. Banyak faktor-faktor lain yang berisiko dengan 
terjadinya preeklamsi seperti obesitas, faktor genetik, faktor suami, riwayat penyakit

\section{Kesimpulan}

1. Jumlah kasus preeklamsi pada ibu bersalin sebanyak 52 orang di RSU Sundari medan Tahun 2014

2. Tidak ada hubungan antara faktor paritas dengan terjadinya preeklamsi pada ibu bersalin.

3. Tidak ada hubungan preeklamsi pada persalinan sebelumnya dengan kejadian preeklamsi

Saran

Diharapkan kepada tenaga kesehatan terutama bidan untuk melakukan penyuluhan tentang pentingnya hamil pada usia reproduksi sehat

\section{DAFTAR PUSTAKA}

Arini. 2012. Mengapa Seorang Ibu Harus Menyusui. Yogyakarta: Flash Books

Chapman. Vicky. 2006. Asuhan Kebidanan: Persalinan dan Kelahiran. Jakarta: EGC

FKUNPAD. 2005. Obstetri Patologi: Ilmu Kesehatan Reproduksi. Ed.2. Jakarta:EGC

Leveno, K. J, dkk. 2009. Obstetri Williams: Panduan Ringkas. Ed.21. Jakarta: EGC

Manuaba, I. A. Chandranita. 2008. Gawat Darurat Obstetri Ginekologi dan Obstetri Ginekologi Sosial untuk Profesi Bidan. Jakarta: EGC 2010. Ilmu Kebidanan Penyakit Kandungan dan KB: Untuk Pendidikan Bidan. Ed.2. Jakarta: EGC

Rustam. 2011. Sinopsis Obstetri: Obstetri fisiologi obstetri patologi. Ed.3. Jil.1. Jakarta: EGC

Morgan, 2009. Obstetri dan Ginekologi: Panduan Praktik. Jakarta: EGC

Notoatmodjo, 2010. Metodologi Penelitian Kesehatan. Ed.Rev. Jakarta: Rineka Cipta

Norwitz, E R. 2010. At a Glance Obstetri dan Ginekologi. Ed.2. Jakarta: Erlangga

Nugroho, T. 2011. Buku Ajar : Obstetri Untuk Mahasiswa Kebidanan. Yogyakarta: Nuha Medika

Rukiyah, A.Y 2010. Asuhan Kebidanan IV: Patologi Kebidanan. Jakarta: CV Trans Info Media

Prawirohardjo, S. 2006. Buku Acuan Nasional: Pelayanan kesehatan Maternal Dan Neonatal. Jakarta: Yayasan Bina Pustaka Sarwono Prawirohardjo.
Pudiastuti, R.D. 2012. Asuhan Kebidanan pada Hamil Normal dan Patologi. Yogyakarta: Nuha Medika

Yulaikhah, L. 2008. Kehamilan. Jakarta: EGC

Addy. 2009. Gambaran Karakteristik Ibu Hamil Dengan Preeklamsi.

http://addy1571.wordpress.com/2009/08/23/gam baran-karakteristik-ibuhamil-dengan-preeklamsidi-rsu/.

Ayurai. 2009. Hubungan antara Usia, Paritas dengan Kejadian Preeklamsia. http://ayurai.wordpress.com/2009/04/21/hubunga n-antara-usia-paritas-dengan-kejadianpreeklamsia/.

Duley.2003.http://repository.usu.ac.id/bitstream/12345678 9/31581/5/Chapter\%20I.pdf.

Harian Analisa. 2012. Peran Strategis Bidan dalam Pencapaian MDGs 2015. http://www.analisadaily.com/news/read/2012/04/ 30/48433/peran_strategis_bidan_dalam_pencapai an_mdgs_2015/\#.UIaRPaAvbMw.

Presdeka. 2011. Faktor Kematian Ibu Hamil. http://eswetty.blogspot.com/2011/06/faktorkematian-ibu-hamil.html.

Satyoputro. 2012. Angka kematian di indonesia. http://www.harianbhirawa.co.id/opini/48212mendorong-percepatan penurunan-aki.

Starberita.2012.Internet.http://www.starberita.com/index.p hp?option $=$ com content $\&$ view $=$ article $\&$ id $=2408$ 2:angka-kematian-ibu-di-sumuttinggi\&catid=158: sosial.

Suparyanto. 2012. Preeklamsi kehamilan. http://drsuparyanto.blogspot.com/2012/06/pree klamsi.html

Tempo.Co. 2012. Pengetahuan Ibu Hamil Angka Kematian Tinggi. http://www.tempo.co/read/news/2012/03/12/ 173389619/Pengetahuan-Ibu-Hamil-MinimAngka-Kematian-Tinggi. 